\title{
THE ROLE OF INTERACTIVE METHODS IN THE DEVELOPMENT OF PRIMARY CHILDREN'S CREATIVITY
}

\author{
Ph.D. Claudia VLAICU ${ }^{1}$, \\ PhD. Ramona NEACSA ${ }^{2}$, \\ Faculty of Theology and Sciences of Education, \\ Valahia University of Târgovişte \\ ROMANIA \\ Email $^{1}$ : vlaicu.claudia@gmail.com \\ Email $^{2}$ : ramonaneacsa@gmail.com
}

\begin{abstract}
Primary children's education requires from educators the use of a wide range of methods. The more creative the personality and methods of education of teachers, the more creative classes become. The present paper is a theoretical approach intended to emphasize the role of interactive teaching methods in the development of creative thinking of primary pupils. There is a theoretical part, presenting the inventory of the most efficient methods, a methodological part, with the specific aspects of each method when applied and an analytical part, encompassing the SWOT analysis of each, as well as obstacles that teachers may encounter when using them in class. The conclusions will envision the psychological and methodological implications of using such methods that develop the creativity of primary children. A special attention is paid to the experiential domains each method is applied mostly to and to the way primary teachers should develop their own creative style of teaching. Several directions of teaching research methodology shall be drawn in relation to this topic.
\end{abstract}

Keywords: primary teaching; education; creative thinking; creativity;

\section{INTRODUCTION}

The theoretical approach of this theme envisions the theories of creativity and creative thinking on the one hand and the inventory of interactive methods which help the former develop and blossom on the other hand.

Contemporary society is characterized by radical changes which take place not only in science, technique or culture but also inside human brain. It has already been proven that children think faster than their one hundred years ago fellows. The accelerated thinking comes along with performance and progress not only in science and technology but also in the creative thinking inside human brain.

If "The last two decades have given greater importance to an education based on shaping and developing the students" cognitive and functional action skills. (...) Today's society requires an education guiding learning to a pragmatic, valid storage of knowledge

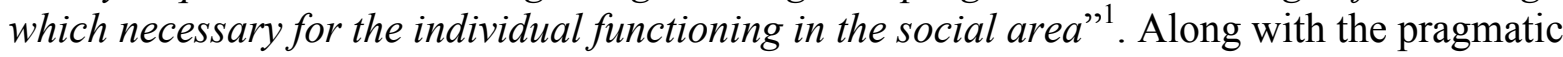
view, it is necessary for the education specialists to equally emphasize the creative side of

\footnotetext{
${ }^{1}$ Alina Anghel, Modern Teaching Assessment and Implications of Learning Motivation. In Revista Romaneasca pentru Educatie Multidimensionala. June, 2017 ,Volume 9, Issue 19(1), 65-66
} 
the process. The efficiency of the learning process requires a creative teaching adapted to each student's needs and skills. The performer student of the future, regardless of how pragmatic the approach on knowledge may be has to go through a process infused by creativity. Every invention and every performance in any field of knowledge cannot but be proceeded by a creativity process. And creativity, either we understand it in terms of process, product or trait of personality is nevertheless a work in progress. This paper is meant to discuss how interactive methods used in primary years help children develop their creativity in language and communication classes.

\section{THEORETICAL BACKGROUND}

The theoretical background of this paper encompasses two theoretical approaches: the interactive methods and creativity. Romanian classifications of the interactive group methods and techniques proposed by the prominent personalities of the Romanian pedagogy translate the ones which have already been used and discovered in Europe. For the past ten years, Romanian methodologists have chosen the ones that group them according to their main didactic function ${ }^{2}$.

1.Interactive group teaching-learning methods and techniques: reciprocal teaching as a learning method, the Mosaic method, Comprehensive learning, Waterfall, STAD- the Method of learning in small groups, The method of team contests, The method of swapping pairs, The Pyramid method, Dramatized learning, Heuristic conversation, Group debate and discussion, Group problematization, Didactic game, Case study, etc.

2. Interactive methods and techniques meant to consolidate and systematize the pupils' knowledge and to provide an alternative check-out/evaluation of their knowledge: cognitive/conceptual map, Matrixes, Cognitive chains, Causes and effects diagram, Cobweb, The Lotus Flower Technique, The RAI method, Lighted cards, Individual and/or group portfolio, Reflexive diary, Case study, Investigation etc.

3. Creativity-boosting problem solving methods and techniques: Brainstorming, Stellar explosion, The Method of the Thinking Hats, The Carousel, Multi-voting, Round Table, Group Interview, Philips 6/6, The 6/3/5 Technique, Creative controversy, The Frisco Method, Synectics, The Delphi Method etc.

4. Group research methods: group research topic/project, team experiment, group portfolio, etc.

We will focus (selectively) on some of the methods and techniques meant to develop creativity in language and communication classes.

As for creativity at primary children, we have followed the natural historical approach of it: $^{3}$ :

a. Guilford J.P. (1950) who envision creativity along with the abilities and skills we encounter at most people; he was interested in the way the creative personality manifests through skills, attitudes and temperamental qualities.

b. Allport G.W. , who considers that creativity can't be limited to just some categories of personality instance: skills, attitudes and temperament qualities.

c. Gallton F. (1869) thinks that genius people are endowed with exceptional intellectual and mental skills.

\footnotetext{
${ }^{2}$ Oprea, C.-L.- Strategii didactice interactive (Interactive Didactic Strategies), E.D.P, 2008, p.256

${ }^{3}$ Synthesis from the book entitled Creativity, Anoiko, 2011, downloaded from

https://oiko.files.wordpress.com/2011/03/2011_wiki_anoiko_creativity1.pdf
} 
d. Cattell J.M. (1903) studied the activity and life of one thousand personalities and reached the conclusion that they are defined by exceptional hereditary qualities.

e. Weisberg R. Considers that all creative personalities (where there is creation there is a genius too) have a certain number of common features amongs which are: knowledge interests, judgement intelligence, self-confidence, intuition and a form of self perception as a creative individual. He states that at present it is little known about the characteristics of a genius, the concept in itself being a myth. He brings forth the following arguments:

a. The psychological traits may not causally relate to the creative activity

b. Creativity does not manifest not even to the greatest artists or scientists, which indicates the fact that genius is not a constant trait; individual.

c. Genius is a characteristics that the society atributes to the work results of an

As for the interpretations of the Romanian psychologists, almost all of them cover the directions envisioned by world wide specialists. Thus, Rădulescu - Motru talked about creation in terms of energetic personality and vocation; Ralea M. Considers originality much closer to feelings than to intellectual factors; Pavelcu V. Considers the creative personality as integrating specifically the motivations of the individual; Odobleja Ş. tried in the work named Consonant Psychology (1938) to operationalize the cognitive elements of discovery and invention in an operational sui-generis model of relation which possesses the tridimensional model of the intelligence issued by Guilford (1967) or the model of creative thinking belonging to Torrance (1974) ${ }^{4}$. Munteanu Anca in her work entitled „Incursion in creatology" offers information about creativity in all fields of knowledge. She states that being creative means seeing the same thing as everybody else but thinking of something different ${ }^{5}$. Roşca Al. emphasizes the complexity of the phenomenon and argues that it is impossible to reach a cooomn ground when it comes to defining creativity since each authors places a different accent on a specific dimension.

He states that according to some authors „, creativity is the capacity to produce something new and valuable" and according to others it is a process leading to product ${ }^{6}$. According to Popescu - Niveanu P. (1987) ,creativity involves a general personality setting towards something new, to a certain form of organization of the psychic process within the personality system". He considers the creative personality the one characterised by the proper interaction between aptitudes and attitudes ${ }^{7}$. Boden Margaret A. (1992) considers creativity as being ,performing new original combinations amongst old ideas”. The new combinations should have a certain value ${ }^{8}$.

One of the most valuable interpretation of creativity could be found in contemporary works belonging to W. Duff issued in XVIII century. The hypothesis of his theory is rooted in the analysis of genius minds like Platon, Shakespeare, Descartes, Bacon, Newton sau Berkeley.

\footnotetext{
${ }^{4}$ Synthesis and translation from Gabriela Popescu, Psihologia creativității, Ed.Fundației România de Mâine, București, 2007, p.11-123

${ }^{5}$ Anca Munteanu, Incursiune în creatologie,Timișoara: Augusta, 1994, pp. 309-314

${ }^{6}$ Roșca, Al., Creativitatea generală și specifică. Ed. Academiei, București, 1981, p. 16

${ }^{7}$ Gabriela Popescu, Psihologia creativității, Ed.Fundației România de Mâine, București, 2007, p.7

${ }^{8}$ [8] Margaret A. Boden, The Creative Mind, Myths and mechanisms, second edition, Routlege, London and New York, 2004; downloaded

https://pdfs.semanticscholar.org/52f1/53075b22469fa82ecb35099b8810e95c31f6.pdf
} 
W. Duff distinguished three faculties of the creative mind: imagination, judgement and taste ehich he considers to be the main components of genius. He states that imagination goes hand in hand with divergent thinking and judgement with convergent thinking. Taste is approached as an extrajudgement more of an esthetic nature, conferring elegance to our thoughts ${ }^{9}$. Teresa Amabile (1983) considers that making decisions involves the process of creativity many times. On the one hand, the creative solutions assures solving the problem with an unexpected efficiency and on the other hand they display an amazing elegance and simplicity ${ }^{10}$.

She states that creativity encompass the following three components:

1. qualification, the degree of specialization in the respective field.

2. Creative abilities include a cognitive and a perceptual one favourable for tacking a problem

3. Intrinsic motivation presuposes the preparation for an activity that seems fascinating and generates glee and satisfaction.

So, what is creativity, after all and how can we approach it, know it and stimulate it? The theories of famous researchers like Kubie, Piercon, Bejan, Piajet J., Richard, Muchielli R., Vîgotskii L. Or the ones mentioned above may be a possible answer.

If we were to conclude, creativity is the capacity to produce new products which are at the same time original and effective.

As for creativity structure, research done by Gollann (1963) envisions several approaches:

a. Creativity as a personal characteristic;

b. Creativity as a product;

c. Creativity as a specific process ${ }^{11}$.

Along with the development of pre-school learning, special attention has been paid to the development of creative tools and methods which are meant to stimulate children's abilities to learn. The process of developing a child's creativity follows almost the same structure, both focussing on the interdependence between the creative process, the creative product and the creative personality.

\section{ARGUMENT OF THE PAPER}

Our opinion states that even if not all children are creative, a good teacher should be a creative personality who is able to use creative methods of teaching. Teaching creatively and using creative methods is not one and the same thing.

But one compelling request for a teacher who wants to get creative students is to rely his teaching on the methods and techniques meant to develop creativity. Our paper today relates only to methods and techniques used in language and communication classes.

\section{ARGUMENTS TO SUPPORT THE THESIS}

One strong argument to support our thesis is rooted in the importance of creativity in language and communication classrooms. Why is creativity important in language classrooms? First of all, the very use of a language is a creative act: we transform thoughts into language that can be heard or seen. We are capable of producing sentences and even

\footnotetext{
${ }^{9}$ Encyclopedia of Creativity, vol. I, Academic Press, electronic edition, 1999,p. 316

${ }^{10}$ Amabile, Teresa M.; Barsade, Sigal G; Mueller, Jennifer S; Staw, Barry M., "Affect and creativity at work," Administrative Science Quarterly, 2005, vol. 50, pp. 367-403.

${ }^{11}$ Gabriela Popescu, Psihologia creativității, Ed.Fundației România de Mâine, București, 2007, p.14
} 
long texts that we have never heard or seen before. Secondly, children do not master the level of an adult when it comes to expressive language, so teachers have to often use creative methods for making up for lack of language in a communicative situation (e.g. miming, drawing, paraphrasing used for getting meaning across). Other relevant aspect refers to the fact that most children become more motivated, inspired or challenged if they can create something of value, if they feel that in some ways what they do and how they do reflects who they are. Derived from here is the consequence that creativity improves self-esteem as learners can look at their own solutions to problems and their own products and see what they are able to achieve.

Creative work in the language and communication classroom may lead to genuine communication and co-operation. Learners use the language to do the creative task, so they use it as a tool, in its original function. This prepares learners for using the language instrumentally outside the classroom.

Creative tasks enrich classroom work and encourage collaborative learning. The process of learning in itself becomes more enjoyable by tapping into individual talents, ideas and thoughts - both the learners' and the teacher's. Creative thinking is an important skill in real life. In order to think creatively one needs to be first encouraged and taught to do so. One needs to understand that creative thinking is part of our survival strategies and it is a force behind personal growth and the development of culture and society.

\section{ARGUMENTS TO ARGUE THE THESIS}

The theoretical arguments that could contradict the thesis of the paper may start with the very course of society development: more and more the emphasis is laid on developing performers and not complete personalities. The performer student of the future has got a more pragmatic approach on knowledge. He is encouraged by family or society culture to focus on one job that he may be good at and which may get him or her financial benefits. Rarely are the children encouraged to seek personal growth along with the other basic needs. Our children are taught to seek financial stability and only then they may be allowed to pursue their talents, which are permitted at first instance as hobbies. We haven't witnessed very often school reforms infused by creativity in Romania. We are still committed to getting performers rather than complete and fulfilled personalities. It is a paradox, because after studying the background education and personality history of all inventions and inventors researcher have come to the conclusion that every invention and every performance in any field of knowledge cannot but be proceeded by all stages of a creative process. And creativity, either we understand it in terms of process, product or trait of personality is nevertheless a work in progress.

\subsection{Structure}

While lecturing still tends to be the easiest form of instruction in Romanian schools (although education studies have shown that students absorb the least amount of information that way), things have been switched off a little when it comes to primary and preschool teaching. Along with the primary school reform started in 2008 , an open- minded attitude has considerably helped teachers apply innovating new teaching methods. Although not all teachers correctly understood how to apply the new integrated curriculum, they have gradually strived to accept new ideas even if it looked like strange at the beginning.

\section{Collaborative learning with technology}

Collaborative learning is typically understood to be a situation in which two or more students work together to search for understanding or meaning, or to solve a problem. 
Students might work together to make meaning by creating an artefact or product. Collaborative learning is an important learning strategy for educators to teach and to use in their classrooms. It improves student knowledge by combining strengths, sharing responsibilities and learning from one another, which brings together many opportunities for enriching knowledge.

As everyone knows, the end result of collaborative efforts is always immense. For the last ten years both in kindergartens and primary schools, Romanian teachers have collaborated and have introduced innovative teaching methods. Interactive teaching methods are an effective way to connect with a generation of students used to consistent stimulation and education. But since teachers have to be consistent also with the technological advances in teaching, we suggest Professor Kevin Yee's ${ }^{12}$ advice for how teachers can make their lessons more interactive. He is the author of "Interactive Techniques," a collection of more than 100 teaching strategies - compiled from different sources-that aim to energize students and engage them in lessons.

Some of the techniques look and feel like they might have a different tone to them than your usual mannerisms in class. The most used techniques recommended by him are: Follow the Leader, Total Physical Response (TPR), One Word, Opposite Arguments, Historically Correct, Test Tournament, YouTube Video Quizzes, Electronic Role Playing. Students create their own blogs and write diary-style entries while role-playing as someone central to the content being discussed. Non-formal learning should not be an option but a compelling task of the teachers of the future.

In these learning experiences, students work together towards a common goal and, through the process, depend on each other for their experiences and knowledge.

\subsection{Play and role-play}

The tension within education about play being used as a vehicle for formal and informal learning is a ridiculous one, especially when you think about play as a biological drive. We should be asking ourselves what right we have in not allowing play to be a major part of children's learning experiences. Who do we think we are, suppressing another human being's natural way of engaging with the world?

Adults who tell children not to giggle, laugh, whisper, shuffle in their seats or stare out the window and dream, might as well gag and nail those children to the floor. They're doing just as much harm. Children need to act out what they read and sometimes become one with the characters of the stories. Role-play has been proven to be the most effective method of learning a new unit in language and communication classes. Adults who tell children what, when and how they are going to learn may be confronted with the consequence of stifling every interest or self-pursuit. Creativity emerges within minds which are not properly set for a specific task, spontaneity and freedom of expression should be mixed with play and play-role during communication and language classes.

\subsection{Open questions}

Open questions are often displayed in the classroom and related to the unit of inquiry. In discussion they are often used to discuss the unit of inquiry students were working on. The use of open and closed questions during a lesson may have provided participants with an insight into what individuals in their class knew and could have helped to activate individual's prior understanding and knowledge of a particular concept. Open questions leave room for individual expression, for uniqueness and divergent thinking.

\footnotetext{
${ }^{12}$ Siran Mukerji, Purnendu Tripathi, Cases on Tehnological Adaptability and Transnational Learning: Issues and Chanllenges, Information Science Reference, New York, 2010, p. 416
} 


\subsection{Story telling and creative story retelling}

Stories create magic and a sense of wonder at the world. Stories teach children about life, about themselves and about others. Storytelling is a unique way for students to develop an understanding, respect and appreciation for other cultures as well as using their imagination to innovate and develop language and communication skills.

4.5. Creativity-boosting problem solving methods and techniques: Brainstorming, Stellar explosion, The Method of the Thinking Hats, The Carousel, Multi-voting, Round Table, Group Interview, Philips 6/6, The 6/3/5 Technique, Creative controversy, The Frisco Method, Synectics, The Delphi Method etc.

There is not enough space in this paper to describe each method or techniques and the way it should be applied for a particular unit. Each teacher should get familiarized first with the method and then adapt it to the age and individual particularities of each class and each student. Creativity in teaching means having a wide repertoire of routines and strategies which teachers can call upon, as well as being ready to depart from established procedures and to use one's own solutions. In general we find that novice teachers are much less likely to be creative than experienced teachers simply because they are familiar with fewer strategies and techniques. The danger is that once a teacher becomes comfortable in using a core set of techniques and strategies these become fixed. Another important step is to issue for each class a particular intervention programme for discovering, unlocking and developing the creative potential. Equally important is the teacher's ability to encourage children to solve problems creatively, without the fear of giving the wrong answer, to help them display their individuality, focusing not only on achieving operational objectives but also on the transfer of creative abilities along with the educational process.

Unfortunately, there isn't enough evidence that all primary teachers are concerned with the methods and techniques to stimulate creative skills and abilities of primary children. The ministry of Education or local inspectorates do not have yet an evaluation system to this concern. So it is up to each school and each teacher whether they chose to elaborate and implement an educational programme encompassing creativity development in particular except for those objectives included in the curriculum. Creativity development is still a sensitive educational issue at the practical level although the theories and methodology are very well known. We rarely find objectives related to creativity development in planning and development of extracurricular activities. Finally, serious studies related to the way in which extra school activities influence the creative capacity and children's motivation for studying the school subjects should be published.

\section{DISMANTLING THE ARGUMENTS AGAINST}

In arguing that investment in creative learning should be a priority and not an auxiliary task of Romanian school reform, it is important to keep in mind that young people are more than just a potential workforce, and should not be perceived only in the context of their situation in the labour market. Among future young people are potential philosophers, artists, writers, entrepreneurs, craftsmen and women - people who will create, who will constitute, who will continue Europe's culturally rich and unique traditions. The main message of European Commission has been about the need to improve and widen the recognition of non-formal learning, and not just in relation to employability ${ }^{13}$.

\footnotetext{
${ }^{13}$ European Commission, Developing the creative and innovative potential of young people through nonformal learning in ways that are relevant to employability;

http://ec.europa.eu/assets/eac/youth/news/2014/documents/report-creative-potential_en.pdf
} 


\section{CONCLUSIONS}

Creativity constitutes thus a fundamental issue for the entire primary education system and not only. Its native and social premises should be known from early stages of life so that each educator should adopt the most efficient psycho-pedagogical means and methods for the act of learning both within schools and outside them.

The primary teacher is the one who needs to discover the creative talent and to nourish the proper learning environment to make the creative abilities of their children flourish. He needs to encourage the imagination, the fantasies and the creativity of his students. When the primary children's imagination goes through ebullience, the teacher shall leave the ideas flow and observe the children and their way of solving the problems, the way they ask and answer questions.

Nevertheless, a key requisite is for the teacher to be a creative personality himself or herself. We cannot breed creativity of our children unless we as educators create the proper setting: a proper creative and socio-emotional classroom setting, a proper creative didactic scenario emerging of new and original creative methods of learning and last but not least proper psychological and educational methods of knowing each pupils creative potential.

\section{BIBLIOGRAPHY:}

[1] Alina Anghel, Modern Teaching Assessment and Implications of Learning Motivation. In Revista Romaneasca pentru Educatie Multidimensionala. June, 2017, Volume 9, Issue 19(1), 65-66

[2] Amabile, Teresa M.; Barsade, Sigal G; Mueller, Jennifer S; Staw, Barry M., "Affect and creativity at work," Administrative Science Quarterly, 2005, vol. 50, pp. 367-403.

[3] Anca Munteanu, Incursiune în creatologie,Timișoara: Augusta, 1994,

[4] Apud Encyclopedia of Creativity, vol. I, Academic Press, electronic edition, 1999,

[5] European Commission, Developing the creative and innovative potential of young people through non-formal learning in ways that are relevant to employability;

http://ec.europa.eu/assets/eac/youth/news/2014/documents/report-creative-potential_en.pdf

[6] Gabriela Popescu, Psihologia creativității, Ed.Fundației România de Mâine, București, 2007,

[7] Gabriela Popescu, Psihologia creativităţii, Ed.Fundaţiei România de Mâine, București, 2007

[8] Margaret A. Boden, The Creative Mind, Myths and mechanisms, second edition, Routlege, London and New York, 2004; downloaded https://pdfs.semanticscholar.org/52f1/53075b22469fa82ecb35099b8810e95c31f6.pdf

[9] Oprea, C.-L.- Strategii didactice interactive (Interactive Didactic Strategies), E.D.P, 2008,

[10] Roșca, Al., Creativitatea generală și specifică. Ed. Academiei, București, 1981,

[11] Siran Mukerji, Purnendu Tripathi, Cases on Tehnological Adaptability and Transnational Learning: Issues and Chanllenges, Information Science Reference, New York, 2010,

[12] Synthesis and translation from Gabriela Popescu, Psihologia creativităţii, Ed.Fundației România de Mâine, București, 2007,

[13] Synthesis from the book entitled Creativity, Anoiko, 2011, downloaded from https://oiko.files.wordpress.com/2011/03/2011_wiki_anoiko_creativity1.pdf 